\title{
WYOBRAŻENIA O NARODZIE WE WSIACH PODHALAŃSKICH
}

\author{
NATIONAL IMAGINARIES IN THE PODHALE REGION
}

\begin{abstract}
The article answers the question of the durability of national categories in local village discourses. By presenting the results of the research conducted using the ethnographic method in the villages of Podhale in the first years of the $21^{\text {st }}$ century, it diagnoses the popularity of national ideas in their primordial form and argues that the reason behind the durability of national ideas in common conversations about politics results from the correlation between the national-conservative rhetoric and the village imaginaries that had been created during the multigenerational experience of working on an agricultural farm.
\end{abstract}

Key words: nation; Podhale region; village discourses; social imaginaries; local knowledge; ethnography

\section{Streszczenie}

Artykuł odpowiada na pytanie o trwałość kategorii narodowych w wiejskich dyskursach lokalnych. Relacjonując wyniki projektu badawczego realizowanego metodą etnograficzną we wsiach podhalańskich w pierwszych latach XXI wieku, diagnozuje popularność idei narodowych w ich prymordialnej postaci oraz argumentuje na rzecz tezy, że przyczyną trwałości idei narodowych w potocznych rozmowach o polityce jest dopasowanie narodowo-konserwatywnej retoryki do wcześniejszych wiejskich wyobrażeń wytworzonych w czasie wielopokoleniowego doświadczenia pracy w gospodarstwie rolnym.

Słowa kluczowe: naród; Podhale; wiejskie wyobrażenia; doświadczenia lokalne; etnografia

ANNA MALEWSKA-SZALYGIN Uniwersytet Warszawski, Warszawa E-mail: a.malewska-szalygin@uw.edu.pl

CITATION: Malewska-Szałygin, A. (2017). Wyobrażenia o narodzie we wsiach podhalańskich Sprawy Narodowościowe. Seria nowa, 2017(49). https://doi.org/10.11649/sn.1526

This work was supported by the Institute of Ethnology and Cultural Anthropology, University of Warsaw. No competing interests have been declared.

This is an Open Access article distributed under the terms of the Creative Commons Attribution 3.0 PL License (creativecommons.org/licenses/by/3.0/pl/), which permits redistribution, commercial and non-commercial, provided that the article is properly cited. (C) The Author(s) 2017.

Publisher: Institute of Slavic Studies, Polish Academy of Sciences 
Podhala, w ramach projektu Etnopolitologia, czyli rozmowy z góralami o polityce. Zacytowane wypowiedzi i wiele podobnych składają się na wiejskie dyskursy lokalne dotyczące państwa, władzy, narodu, polityki i demokracji, współtworzące nowotarski „dyskurs o polityce" (Czyżewski, Kowalski, \& Piotrowski, 1997, s. 19), w którym upubliczniane, przetwarzane i negocjowane są lokalne wyobrażenia.

\section{WYOBRAŻENIA}

Według oświeceniowych ideałów nowoczesność uwolniona z przesądów, zabobonów i fantazji miała stać się królestwem racjonalności. Rozumne zarządzanie i dyscyplinowanie miało doprowadzić do „odczarowania” rzeczywistości społecznej (Weber, 2004). Europejczycy mieli kierować się rozumem, w odróżnieniu od ludów prymitywnych posługujących się wyobrażeniami "mistycznymi” (Levy-Bruhl, 1992, s. 66)². Marzenia o dominacji racjonalności w nowoczesnych społeczeństwach europejskich nigdy nie zostały w pełni zrealizowane, co podkreślał Bruno Latour w książce Nigdy nie byliśmy nowocześni (Latour, 2011). Czasy globalizacji okazały się epoką nowych czarów, a badanie wyobrażeń społecznych okazało się kluczowym sposobem oswajania płynnej nowoczesności.

„Wyobrażenie, wyobrażone, imaginarium - wszystko to są terminy, które odsyłają nas do czegoś, co w globalnych procesach kultury jest zjawiskiem zasadniczym i nowym, a mianowicie do wyobraźni jako procesu społecznego" - pisał teoretyk czasów globalizacji Arjun Appadurai (2005, s. 49). Wyobraźnia, która nie jest fantazją ani mrzonką okazuje się „zorganizowanym polem społecznych praktyk, formą aktywności” (Appadurai, 2005, s. 49). Tak rozumiana wyobraźnia ma niezwykłą moc sprawczą realizującą się w wielu dziedzinach życia społecznego. Jej sprawczość obejmuje „władzę sprawowaną przez imaginowane obrazy" (Appadurai, 2005, s. 86). Wyobraźnia popycha do działania, imaginowane obrazy warunkują podejmowanie decyzji. Appadurai rozważa głównie decyzje migracyjne, ale moc wyobraźni jest daleko większa, warunkuje wybory polityczne, jest istotnym składnikiem tożsamości politycznych, pozwala ludziom komentować sprawy publiczne. Wyobraźnia, łącząc informacje i emocje, wytwarza obraz rzeczywistości, wewnątrz którego jednostki decydują, działają, rozważają i oceniają. Tego rodzaju „imaginarium społeczne" nadaje sens podejmowanym praktykom, używanym symbolom, wypowiadanym słowom i umożliwia „wspólne rozumienie spraw” (Taylor, 2010, s. 37).

Badając imaginaria społeczne, warto przyjąć postawę fenomenologiczną zakładającą, że „stykając się z wyobrażeniami, których czasami (...) nie podzielam, albo takimi, które drastycznie odbiegają od "obowiązującego stanu wiedzy» (...) uchylam w ogóle problem ich prawdziwości czy fałszywości. Przyjmuję za prominentnymi praktykami tego podejścia w odniesieniu do "tekstów kultury» - Bachelardem, Jungiem, Eliadem — że prawdą wy-

\section{......}

Wszystkie cytaty z materiałów źródłowych zapisuję kursywą, również te użyte jako śródtytuły. W odsyłaczu podaję numer wywiadu i stronę, z której zaczerpnięte jest przywoływane zdanie lub wyrażenie. Numery odsyłają do transkrypcji wywiadów znajdujących się w Archiwum IEiAK UW.

2 Warto odnotować, że Emile Durkheim inaczej oceniał tubylcze wyobrażenia, pisząc, że "wyobrażenia te to prawdziwe pojęcia" (Durkheim, 1990, s. 412) stanowiące "materię myślenia logicznego" (s. 412). Tym co uwypuklat byt ich kolektywny charakter akcentowany w określeniu "wyobrażenia zbiorowe" (Durkheim, 1990, s. 414) 
obrażeń jest po prostu sam fakt ich istnienia" (Czaja, 2005, s. 173). W przypadku podhalańskich wyobrażeń o narodzie przyjęcie takiej postawy jest konieczne, ponieważ lokalne konstrukcje wyobrażeniowe zwykle zasadniczo odbiegają od światopoglądu badaczy.

\section{WYOBRAŻENIA O NARODZIE}

Autorzy opisujący procesy upowszechniania idei narodowych w Europie (m.in. Gellner, 1991; Hobsbawm, 2010; Kizwalter, 1999; Pomian, 2004) podkreślali znaczenie aspektu świadomościowego. Benedict Anderson mówił wprost o wyobraźni, umieszczając to słowo w tytule swojej książki (Anderson, 1997). Zgodnie z podejściem określanym jako konstruktywistyczne „obywatele wyobrażają sobie, że należą do społeczeństwa narodowego. Według tego stanowiska nowoczesne państwo narodowe wyrasta nie tyle z naturalnych faktów - takich jak język, krew, gleba i rasa - ile z typowego wytworu zbiorowej wyobraźni" (Appadurai, 2005, s. 238). Parafrazując to zdanie, można stwierdzić, że wyniki nowotarskich badań pokazują, w jaki sposób nowoczesne państwo narodowe wyrasta ze społecznych wyobrażeń o tym, że jest zakorzenione w naturalnych faktach takich jak język, krew, gleba i rasa.

W tym miejscu warto zauważyć, że duża część opracowań dotyczących ugruntowywania idei narodowych w Europie operuje bardzo szeroką kategorią społeczeństwa. Tymczasem wyobrażenia stanowiące istotną składową habitusu, podobnie jak habitus są zróżnicowane klasowo, odmienne dla "klas dominujących" oraz „klas ludowych” (Bourdieu, 2006, s. 235). Dla potrzeb badań etnograficznych podział klasowy jest zbyt szeroki. Etnograf nie ma kontaktu z "klasami ludowymi”, a raczej z konkretnymi ludźmi w wybranych usytuowaniach społeczno-kulturowych. Aby przejść od poziomu teorii ruchów narodowych do poziomu wyników badań etnograficznych trzeba wprowadzić kilka poziomów uściśleń, zaczynając od terytorialnych.

\section{KSZTALTOWANIE WYOBRAŻEŃ NARODOWYCH WE WSIACH PODHALAŃSKICH}

Prezentowany projekt badawczy był realizowany na Podhalu, czyli w dawnej Galicji, gdzie proces upowszechniania idei narodowych miał swoją specyfikę. Autonomia galicyjska ułatwiała szerzenie idei patriotycznych: ukazywała się polskojęzyczna prasa, zakładano stowarzyszenia, a nawet stronnictwa polityczne (Kieniewicz, 1982; Kizwalter, 1999; Łuczewski, 2012; Molenda, 1999 i inni). Na wsi ten proces odbywał się wolniej niż w miastach. Badacze podkreślają ogromną pracę Kościoła, a właściwie wiejskich proboszczów organizujących obchody rocznic narodowych (Molenda, 1999, s. 154) i przywołujących w kazaniach ideę Korony Polskiej (Bystroń, 1995, ss. 4-19-420). Tę działalność wspierała „praca u podstaw" wiejskich nauczycieli i lekarzy zaangażowanych w ten proces z powodów ideowych (Molenda, 1999, s. 79). Istotna była też aktywność działaczy ruchu ludowego (między innymi ks. Stanisława Stojałowskiego) oraz pojawienie się czasopism takich jak "Wieniec”, "Pszczółka” czy "Przyjaciel Ludu”. Mimo wszystkich tych starań do chwili odzyskania niepodległości w 1918 roku proces przyswajania idei narodowych na wsi galicyjskiej był wciąż sprawą otwartą. Jakkolwiek Antoni Kroh twierdził, że „o bezdyskusyjnej 
polskiej świadomości narodowej Podhalan można mówić dopiero w drugiej połowie XIX wieku, [kiedy] elity naukowe i artystyczne związały Podhalan z kulturą polską i uczyniły ich świadomymi Polakami" (Kroh, 1999, s. 160), ja przychylam się do bardziej ostrożnych ocen Jana Stanisława Bystronia (1995) i Kazimierza Dobrowolskiego (1966), którzy uważali, że zasadnicza zmiana nastąpiła dopiero w dwudziestoleciu międzywojennym, a przełomową rolę w tym procesie odegrały szkoły powszechne Drugiej Rzeczypospolitej. Jan Molenda uznaje udział chłopów w ruchu oporu w czasie II wojny światowej za dowód ostatecznego ugruntowania „świadomości narodowej” wśród mieszkańców wsi małopolskiej (Molenda, 1999, ss. 36-37).

\section{O PROJEKCIE BADAWCZYM}

Prace terenowe w ramach projektu Etnopolitologia - rozmowy z góralami o polityce prowadzone były we wsiach powiatu Nowy Targ (województwo małopolskie) w latach 1999-2005 wraz z ekipą badawczą złożoną ze studentów i doktorantów Instytutu Etnologii i Antropologii Kulturowej Uniwersytetu Warszawskiego. Badania realizowano metodą etnograficzną, polegającą na długotrwałym przebywaniu w terenie, wejściu w zażyłość z jego mieszkańcami, prowadzeniu wywiadów otwartych, pogłębionych, ustrukturowanych przez dyspozycję badawczą. Wywiady prowadzone w wiejskich domach i obejściach miały formę dialogiczną, te prowadzone na miejskim targowisku przybierały postać wielogłosowych dyskusji. Wszystkie wywiady były nagrywane i transkrybowane. Finalnie zgromadzono 381 zapisów przechowywanych w Archiwum IEiAK UW. Rozmowy prowadzone były z mieszkańcami wsi w wieku od 40 do 80 lat, w większości z wykształceniem zawodowym lub podstawowym (tylko 10\% z nich miało ukończone technikum). Używając w tekście określeń „mieszkańcy wsi nowotarskich” lub „wsi podhalańskich”, mam na myśli naszych rozmówców, co oznacza, że formułowane wnioski odnoszą się do tej właśnie grupy wiekowej i wykształceniowej.

W czasie wywiadów nie używano kwestionariusza, czyli zestawu ściśle określonych pytań. Dyspozycja badawcza, zogniskowana wokół pojęć takich jak naród, państwo, władza, demokracja, polityka, pozwalała rozmówcom na samodzielne konstruowanie wypowiedzi. Ta technika umożliwiła badaczom obserwowanie, w jakim kontekście umieszczane są terminy istotne dla lokalnych rozmów o polityce. Zachowanie kontekstu ułatwiało odtworzenie pól znaczeniowych tych słów i rekonstrukcję wyobrażeń, czynioną ze świadomością, że jest ona w jakiejś mierze konstrukcją polegającą na budowaniu spójnej całości z elementów rozproszonych w zgromadzonym materiale dyskursywnym. Projekt podsumowała książka Wyobrażenia o państwie i władzy we wsiach nowotarskich 1999-2005 (Malewska-Szałygin, 2008) oraz publikacja zbiorowa złożona z tekstów młodych badaczy, zatytułowana Rozmowy z góralami o polityce (2005).

\section{W państwie jak na gospodarstwie}

Najważniejszym odkryciem nowotarskich badań było dostrzeżenie lokalnej "metafory źródłowej" (Turner, 2005, s. 20). Metafora ta, pojawiająca się formie częstych porównań państwa do gospodarstwa rolnego, wprowadzała model władzy autokratycznej, który za Kasznicą można nazwać „gospodarskim” (Kasznica, 1966, s. 22), za Foucault „pastoral- 
nym" (Foucault, 2000, s. 221), a za Weberem „panowaniem tradycyjnym” (Weber, 1975, s. 541). Wyobrażenia o właściwych relacjach w narodowym gospodarstwie były zdecydowanie odległe od oświeceniowych ideałów umowy społecznej, demokracji reprezentacyjnej, władzy kolektywnej i wizji państwa jako systemu instytucji i procedur. Nie przeszkadzało to nowotarskim rozmówcom w znakomitej orientacji w kwestiach bieżącej polityki, w tropieniu aktualnych afer, słowem w śledzeniu i krytykowaniu wartkiego strumienia życia politycznego. Oceny formułowali, odnosząc aktualne wydarzenia do gospodarskiego ideału władzy, co stawało się źródłem głębokiej frustracji, objawiającej się w postaci narzekań, a jeszcze częściej złorzeczeń, wyrażanych zwykle w sarkastyczno-ironicznej formie, z użyciem wielu wulgarnych słów i kwiecistych przekleństw składających się na specyficzną poetykę wypowiedzi.

\section{Naród jak rodzina $w$ domu}

Logiczną konsekwencją przyjęcia gospodarskiej metafory źródłowej jest porównanie narodu do rodziny pracującej w gospodarstwie rolnym. Przeniesienie wyobrażeń o powiązaniach wewnątrzrodzinnych na skalę państwa wytwarza przekonanie o istnieniu pierwotnej więzi rodowej spajającej naród - rodzinę rodzin. To „primordialne” (Shils, 1957, s. 130) podejście stanowi podstawę wielu pochodnych konstruktów wyobrażeniowych. Jednym z powtarzających się jest przekonanie o posiadaniu wspólnych przodków narodu polskiego. Przekonanie, że Polskość to rodowód przede wszystkim. Korzenie! (...) To skąd się wywodzi. Najstarszy ród! (223, s. 1) często pojawiało się w rozmowach. Naród, jak wielkie rodziny góralskie, łączy wspólnota pochodzenia: Jestem Polakiem, bo to jus przodkowie moi w Polsce cały cas, nie?! Tu som nasze korzenie! (221, s. 1). W tych wyobrażeniach naród łączy wielopokoleniowa więź przypominająca tę, która silnie spaja góralskie rody. Więź ta jest uważana za determinującą i niezbywalną, a przy tym stanowi ona podstawę licznych powinności i przywilejów.

\section{Wspólna krew}

Przekonanie o genealogicznych powiązaniach, zwykle syntetyzowane w słowie korzenie, niekiedy było wyrażane sformułowaniem wspólna krew. Rozważania o krwi pojawiały się nie tylko w rozmowach o przodkach i krewnych; zdarzyło się, że zostały użyte w odniesieniu do sąsiadów - słowackich mieszkańców spiskich wsi powiatu nowotarskiego. Spisz to region częściowo należący do państwa polskiego, częściowo słowackiego (dawniej czechosłowackiego), przy czym granica państwowa dzieląca region zmieniała się kilkakrotnie i ustabilizowała dopiero w 1958 roku. W czasie jednej z wielogłosowych dyskusji nagranych na nowotarskim targowisku padło sformułowanie, że Spiszacy są niedotartymi Polakami (223, s. 1). Jeszcze 20 lat temu, jak jechali do Nowego Targu to mówili, że do Polski jadą! A jak się do nich zajechato, to mówili "o Polacy przyjechali” (222, s. 7). Prośba badacza o objaśnienie określenia niedotarty Polak sprowokowała dalszy wywód: to tak jak mówią o zwierzętach, że jedno ma rodowód, a drugie nie, ale pokolenie przechodzi i on dostaje ten czysty rodowód. To tak Spiszacy z czasem dotrą się i staną twardymi Polakami, bo na razie no niby mają obywatelstwo [polskie - A. M. S.], ale czystej krwi to pokolenie nie jest, dopiero później czyste się stanie (223, s. 3). Komentując te wypo- 
wiedzi, zaskakujące dla badaczy, warto zauważyć, że teorie związane z „czystością krwi” upowszechnity się w dyskursie elit europejskich pod koniec XIX wieku, kiedy, jak pisze Krzysztof Pomian, upowszechniła się skłonność do „zakorzeniania narodu w naturze W "glebie», "rasie» i w "krwi»" (Pomian, 2004, s. 156). Tego rodzaju podejścia, skompromitowane przez rasistowską antropologię czasów nazizmu, zniknęły z dyskursu akademickiego, jednak jak pokazuje współczesny materiał terenowy taka forma objaśniania różnic narodowych wciąż funkcjonuje w wiejskim dyskursie lokalnym, zachowując swój stygmatyzujący potencjał.

\section{Ziemia po Ojcach}

Porównanie narodu do rodziny powodowało, że nowotarscy rozmówcy włączali do swoich wypowiedzi kwestię własności ziemi, będącej na Podhalu wartością rodzinną. O przywiązaniu do wąskich kawałków ziemi dziedziczonej po Ojcach mogą świadczyć nieudane próby komasacji gruntów podejmowane przez kolejne władze od XVIII wieku. Ciekawym materiałem dyskursywnym są też wypowiedzi kobiet, które wżeniły się w góralskie rodziny i boleśnie uczyły się tutejszych zasad związanych z ziemią: tu się każdy bardzo poczuwa do ziemi. (...) Tu się liczy własność ziemi, posiadania. Te ich miedze! O których ja nawet nie wiedziałam, że takie ważne! To też jest polskość! Ja tu tyle przeszłam! Ile łez wylałam! Ja dobrze wiem, co to znaczy ta ich ziemia! Ten kawatek ziemi to jest ich ta polskość, której bronią z dziada pradziada (221, s. 2, 8).

Jak dla rolniczej rodziny fundamentalną wartością jest ziemia odziedziczona po przodkach, tak dla narodu konstytutywne jest terytorium państwa postrzegane jak wielkie narodowe gospodarstwo. Emocjonalny stosunek do ojcowizny rozmówcy przenosili na przywiązanie do ojczyzny: Pani mówi o państwie. A wie Pani, to jest tak, Polska to jest nasza Ojczyzna, czyli ojcowie nasi tu już byli. Polska to jest nasz kawałek ziemi, czyli nasza Ojczyzna, a państwo to jest aparat wyzysku! (116, s. 3); Ojczyna? Ojczyzna to jest kraj, w którym żem się urodzit i po prostu mieszkam. To uważam, mienie po ojcu! To wszystko to jest Ojczyzna! (234, s. 2). Istnienie tego rodzaju wyobrażeń w XX wieku diagnozowali Stanisław Ossowski (1984) i Józef Tischner (2005). Materiały terenowe pokazują, że w pierwszej dekadzie XXI wieku są one wciąż aktualne.

\section{Miłość Ojczyzny}

Według lokalnych wyobrażeń naród konstytuuje wielopokoleniowa więź rodowa, wspólnota ziemi oraz trudny do wyrażenia słowami ładunek uczuciowy, określany jako miłość ojczyzny. Targowi rozmówcy mówili: Ojczyzna? - to nie jest podyktowane jakąś logiką czy rozumem, to jest gdzie indziej zupetnie, to jest jakieś tam uczucie! A z tym tak jak z mitością, na to nie ma lekarstwa! $(218$, s. 2). Większość z nich miała problem z opisaniem tego uczucia. Często stosowano słowa - symbole, będące kondensacją ogromnego bagażu emocjonalnego ujmowanego w szczere wyznania:. Czujem tak, że jestem Polakiem! I zawsze chwale Polskę i czujem, że jestem w swojej Ojczyźnie. Trzeba tą swoją Ojczyznę kochać, bronić i szanować! Ona jest dla mnie wszystkim! (233, s. 1). Ten komponent emocjonalny dopełnia porównania narodu do rodziny, którą prócz wspólnych przodków i dziedziczonej ziemi łączy uczucie miłości, owocujące tęsknotą, gdy rodzina zostaje rozdzielona. 
Praktykowane od ponad wieku góralskie wyjazdy do Ameryki oraz obecnie popularne migracje zarobkowe do państw Unii Europejskiej uzmysławiały rozmówcom przywiązanie do ojczyzny. Wielu z nich podkreślało, że właśnie doświadczenie migracji w szczególny sposób uświadamia człowiekowi istnienie tego uczucia: Dla mnie Polska jest Ojcyzna! No, cy bym pojechat w Ameryke, cy nie w Ameryke kendyś, to będę się cut Polakiem stale! Tak jes i chyba jus bendzi! $(224$, s. 5). Migracja zarobkowa zwykle opisywana jest jako niechciana konieczność i doświadczenie trudne emocjonalnie: przyjdą Święta to myśli się! To widzi się to! Teskni się, no! Za rodziną i za wszystkim! Jak przyjdą Święta to byś przyjechat do Polski, ale nie raz robota rzuci i trzeba iść dalej! $(222$, s. 9). Za rodziną i za Polską tęskni się tą samą tęsknotą i w sferze uczuć trudno rozdzielić te dwa wymiary przynależności, tęsknota za domem zlewa się z tęsknotą za ojczyzną.

Wspólnoty emigranckie generują „nie tylko nostalgię, ale również realne społeczne ruchy" (Appadurai, 2005, s. 261). Na Podhalu jest to dobrze widoczne. Wymownym dowodem takich działań są tablice wmurowane w ściany kościołów czy szkół w powiecie nowotarskim informujące o finansowym wsparciu członków wspólnoty lokalnej pracujących za granicą. Mała ojczyzna, podobnie jak rodzina zasługuje na finansowe wsparcie tych, którym się powiodło na emigracji, którzy chcą zaznaczyć swoją więź ze społecznością, którym zależy na budowaniu autorytetu rodziny, bo przecież jej członkowie wciąż mieszkają w rodzinnej wsi.

\section{Polska mowa}

Zdaniem rozmówców w procesie budowania narodowej tożsamości istotną rolę pełni język, bo jak mówiono, to jus się od ojców nauczy sie człowiek gadania w Polsce, bo jak jus Polak jest, to niech mówi tą polską mową, nie?! W ojczystym języku! (222, s. 1). Język stawał się znaczącym wyznacznikiem zwłaszcza w warunkach emigracji, bo jak uważano, nieważne gdzie jesteś, zawsze jesteś Polakiem, jak po polsku mówisz! (177, s. 7). W warunkach długotrwałej emigracji zarobkowej zachowanie języka polskiego było traktowane jako dowód przywiązania do polskości. Ludzi, którzy już po paru latach pobytu w USA mówili wtrącając angielskie słowa, oceniano bardzo negatywnie, zaś tych, którzy mimo wielu lat spędzonych poza ojczyną mówili bez naleciałości i bez obcego akcentu podziwiano: jak ja byłem $w$ Stanach to był facet, co był tam 30 lat i jak przyszło rozmawiać - on czysto po polsku! On naprawde był Polakiem! (222, s. 1). Język ojczysty był uważany za dowód przynależności do wspólnoty narodowej, podobnie jak swobodne posługiwanie się gwarą góralską świadczyło o tożsamości regionalnej. Co znamienne, w kwestii nauki języka podkreślano rolę szkoły, która obowiązkowo powinna nauczyć dzieci języka polskiego, a na zajęciach dodatkowych także gwary góralskiej. Nikt z targowych rozmówców (w większości byli to mężczyźni) nie uważał, że dzieci powinny uczyć się języka w domu. Zakładano, że używany na co dzień język jest zanieczyszczony wulgaryzmami i powinien być szlifowany w szkole, ta konstatacja dotyczyła zarówno polszczyzny jak i gwary.

\section{Dzieje narodu}

Mówiąc o więziach łączących naród, nowotarscy rozmówcy podkreślali znajomość dziejów narodu. Ich zdaniem, podobnie jak każda rodzina pielęgnuje wspomnienia o przodkach, naród powinien znać swoją historię. Autorzy tych słów nie mieli na myśli podręcz- 
nikowej wiedzy historycznej z jej przywiązaniem do dat, faktów, chronologii i ścisłości. Istotną dla wychowania patriotycznego była silnie mityzowana opowieść o przeszłości, uwypuklająca etyczno-moralne przesłania minionych zdarzeń. Przeszłość opowiedziana w konwencji mitycznej umacnia i uzasadnia poczucie wspólnoty. Więziotwórcza funkcja mitu "wydaje się niezastępowalna, a w szczególności niemożliwa do usunięcia na rzecz przeświadczeń regulowanych kryteriami wiedzy naukowej" (Kołakowski, 2003, s. 118). To przekonanie autora Obecności mitu często znajdowało potwierdzenie w wypowiedziach nowotarskich rozmówców, którzy niewiele pamiętali z lekcji historii w peerelowskiej szkole i nie ubolewali nad tym, uważając, że prawdziwej historii nie można otrzymać w szkole. Znajomość dziejów narodu przekazywana jest przede wszystkim w rodzinie i w kościele. Mówiąc o przekazie wewnątrzrodzinnym, często jako źródło wiedzy patriotycznej wskazywali dziadków wykształconych w wiejskich szkołach w dwudziestoleciu międzywojennym (maksymalnie czteroklasowych). To dziadkowie opowiadali o polskich królach i zwycięstwach, o zrywach narodowych i o odwiecznych wrogach narodu. Ważnym sposobem nabywania wiedzy o przeszłości jest też bezpośredni przekaz doświadczeń: to jest przekazywane przez ojca i matke. No moja babcia była na wojnie i dziadek też i jak ja rostam to oni mi to przekazywali, dlaczego była wojna? Dlaczego ja jestem Polką? (221, s. 1). Wychowanie patriotyczne to nie tylko przekaz ustny, to również wspólne działania, a zwłaszcza świętowanie: Są dzieci - to jest to przekazywanie: wspólne wigilie, wspólne święta. To wszystko jest to wychowanie! (221, s. 6), bo jak podkreślano, to wszystko od wychowania zależy! No, bo po trosze szkoła, ale to bardziej zależy, jak kogo rodzice osobowościowo wychowują (224, s. 6). Wdrażanie we wspólnotę rodzinną jest, jak podkreślali rozmówcy, nierozłącznie powiązane z ugruntowywaniem poczucia wspólnoty narodowej. Procesy te są w praktyce społecznej nierozdzielne.

Znajomość dziejów narodu okazywała się znacząca zwłaszcza na emigracji, kiedy stanowiła arsenał argumentów podbudowujących poczucie godności ludzi wykonujących prace niecieszące się społecznym poważaniem. Rozmówcy opowiadali nam, jak po wspólnej pracy, rozmawiając przy alkoholu z innymi robotnikami, Meksykami, Portorykami czy Iriszami, przywoływali przede wszystkim postać Jana Pawła II, ale też innych bohaterów narodowego panteonu (często uzupełnianego o znanych sportowców), po to by pokazać polską dumę i charakter narodowy.

\section{Charakter narodowy}

Koncepcja specyficznego charakteru poszczególnych narodów okazywała się ważna zarówno w wielogłosowych rozmowach o polityce, jak i w sytuacjach odbioru przekazu medialnego. Wiedza o Ruskich, o Niemcach, o Arabach pozwalała komentować bieżące wiadomości polityczne, odnosząc je do wcześniejszych wyobrażeń o stosunkach międzynarodowych. Silnie mityzowane wizje przeszłości stanowiły podbudowę stereotypowych wizerunków narodów. Jak wynikało z obserwacji badaczy, większość komentarzy czynionych przy słuchaniu czy oglądaniu wiadomości rozpoczynała się od stów: wiadomo, Ruscy to tak zawsze.... Albo: no, Niemcy to tak sobie lubią. Ich autorzy wypowiadali się tak jakby mieszkańcy państw ościennych, zawsze opisywani w kategoriach narodowych, mieli określony charakter, o którym można wnioskować z minionych doświadczeń, a który pozwala zrozumieć ich obecne działania, a nawet przewidzieć przyszłe. Ten spersonalizowany, naznaczony stereotypami sposób opowiadania o stosunkach międzynarodowych bardzo przypominał opowieści o sąsiedzkich sporach pomiędzy nowotarskimi rodzinami. 
Przekonanie o istnieniu charakteru narodowego było powszechne i często nagrywaliśmy wypowiedzi mówiące o tym, że naród polski jest taki, że jakby przyszła jaka wojna, to wszyscy wezmą, tak jak dawno było, sierp i kosę i będom pomagać (87, s. 2). Niestety w czasach spokojnych Polacy sie swarzą i do rządzenia nimi Potrzebna jest twarda ręka! (353, s. 5), bo dla Polaków to rząd silnej ręki jest najlepszy! (260, s. 2), albowiem Polak Polakowi to, jak to się mówi, tyżkę wyrwatby z ręki, a Żyd Żydowi krzywdy nie zrobi! (200, s. 6). Koncepcja charakteru narodowego dopełnia porównania narodu do góralskiej rodziny rozszerzonej. Góralskie rody również postrzegane są jako obdarzone specyficzną kolektywną, wielopokoleniową osobowością, której znajomość ułatwia codzienne kontakty

\section{Katolicyzm}

Religia, a właściwie religijność była często podkreślanym spoiwem narodowej wspólnoty: czym jest Polskość? No to ta ziemia, ludzie, miłość, no i ten katolicyzm, co chodzimy do kościoła, może ta wspólnota, wychowanie dzieci... (221, s. 5). Katolicyzm wydawał się rozmówcom w sposób nierozerwalny powiązany z polskością, uważano go za fundament więzi łączącej wspólnotę narodową, podstawę wychowania dzieci i wspierania zachowań etycznych.

\section{CZEMU GÓRALE STALI SIĘ PRYMORDIALISTAMI?}

Podsumowując ten skrótowy przegląd materiałów źródłowych, wypada stwierdzić, że wszystkie lokalne skojarzenia wiążące się ze słowem naród odnoszą się do wyobrażenia państwa jako wielkiego gospodarstwa. Gospodarska metafora źródłowa wyznacza ramy relacji państwo - społeczeństwo, opisywanej z pomocą lokalnej poetyki, w której naród jest postrzegany jak rolnicza rodzina: dziedzicząca ziemie po przodkach, stanowiąca wielopokoleniową wspólnotę powiązaną więzami krwi, wspólną własnością, uczuciem miłości, specyfiką języka, pamięcią o przodkach oraz szczególnym charakterem i podzielaną religijnością. Taki zestaw wyobrażeń śmiało można zdiagnozować jako prymordialny, czyli taki, w którym "naród jest definiowany jako unikalna, spójna, wieczna i niezmienna grupa psycho-społeczna (wyposażona w charakter czy też ducha narodowego), oparta na wspólnocie pochodzenia, religii i moralności, a także przywiązania do ziemi ojców" (Łuczewski, 2012, s. 87)

Zestawiając wyniki badań prowadzonych we wsiach powiatu Nowy Targ z wynikami prac badawczych Michała Łuczewskiego prowadzonych w Beskidzie Wyspowym, śmiało mogę rozszerzyć jego diagnoze „ż̇miącanie są prymordialistami' (Łuczewski, 2012, s. 574) na mieszkańców wsi Niżnego Podhala. Nie do końca natomiast mogę zgodzić się z twierdzeniem autora Odwiecznego narodu, że „chłopi stali się Polakami - prymordialistami dzięki Josephowi de Maistre. Jego ideologia została przejęta przez polskich ultramontan i ks. Stojałowskiego, który sięgając po metody działania ruchu społecznego, przekazał ją wsi" (Łuczewski, 2012, s. 574). Doceniając wpływ działaczy chłopskich (których wkładu w upowszechniane idei narodowych nie sposób przecenić), nie uważam, że mieszkańcy wsi nowotarskich zostali prymordialistami „dzięki Josephowi de Maistre”. Źródeł wiejskiego prymordializmu upatrywałabym raczej w dopasowaniu idei narodowo-konserwa- 
tywnych do kategorii myślowych wytworzonych w procesie interpretowania wielopokoleniowego doświadczenia pracy $w$ gospodarstwie. Idee prymordialne dobrze pasowały do kategorii uprzednich, które zostały wypracowane znacznie wcześniej i rezonowały z codziennym doświadczeniem mieszkańców wsi. Kategorie, które pozwalały rozumieć mikroświat gospodarstwa, rodzinnej wsi i okolicy, wystarczyło jedynie rozszerzyć na skalę państwa. Retoryka narodowo-konserwatywna przeniknęła do lokalnych dyskursów dlatego, że jej pojęcia pasowały do wcześniej istniejącego imaginarium. Owo imaginarium stanowiło poznawczy grunt umożliwiający internalizację idei narodowych.

\section{NARÓD CZY OBYWATELE?}

O ile pojęcie „naród” nowotarscy rozmówcy sami wprowadzali do rozmowy, o tyle pojęcie "obywatel" nie pojawiało się w ich wypowiedziach, jeśli badacz nie zapytał o nie wprost. Wprowadzone przez badacza, uruchamiało niekiedy zaskakujące skojarzenia: No, teras jus ni ma obywateli. Badacz: A co to słowo znaczyło dawniej? Rozmówca: No, obywatel to pan $(224$, s. 8). Starsi rozmówcy używali tego określenia w znaczeniu obywatel ziemski, przywołując historyczne użycie tego terminu stosowane do II wojny światowej, a odwołujące się do tradycji Pierwszej Rzeczypospolitej, kiedy to „szlachcic był obywatelem na długo przed swoim urodzeniem, ponieważ członkowie jego rodziny zawsze byli obywatelami państwa" (Thomas \& Znaniecki, 1976, ss. 186-189), mającymi prawo decydowania o sprawach polityczno-publicznych.

Inne znaczenia słowa "obywatel" wydobywa kolejny cytat z nowotarskich wypowiedzi: "obywatel" to było tak za komuny raczej używane. (...) Ja stowo obywatel to z wojska znam, bo tam nie było na pan, ale obywatelu do każdego. "Obywatelu majorze", "obywatelu sierżancie", tak się mówiło (229, s. 1). Socjalistyczny obyczaj wymagał użycia tej formuły w relacjach ze służbami mundurowymi. Milicjant zwracał się do zatrzymywanego, używając zwrotu "obywatelu”, a zatrzymany odpowiadał zwrotem "panie władzo". W efekcie słowo "obywatel" w czasach PRL kojarzyło się ze zwierzchnością: wtedy, kto pełnit te funkcje państwowe to obywatelem się nazywat. Milicję i wyższych urzędników tak nazywali (229, s. 2). Peerelowskie powiązanie terminu "obywatel” z urzędnikami i zwierzchnikami stanowi kontynuacje dawniejszych konotacji. W obu przypadkach obywatel to człowiek postawiony wyżej w hierarchii społecznej.

Rozmowy dotyczące narodu toczyły się wartko, wzbudzały wiele emocji angażowały naszych rozmówców. Pytania dotyczące znaczeń słowa „obywatel” przypominały odpytywanie z niepamiętanej lekcji szkolnej. Ewidentnie nie było to pojęcie, którego używano na co dzień. Dobrym przykładem może być konfuzja, jaką budziła prośba o objaśnienie nazwy partii Platforma Obywatelska. W wielogłosowej dyskusji targowi rozmówcy zastanawiali się nad słowem „platforma”, łącząc je najczęściej z placformą używaną do przewożenia węgla z wagonów kolejowych do gospodarstwa. Przymiotnik „obywatelska" odczytywali jako pańska, uważając, że: PO to liberałowie, Żydzi i szlachta (406, s. 1), No to bogacze. Jak dawna szlachta, prosze panią! (406, s. 1), To partia dla bogatych ludzi, tych z górnej pótki! (423, s. 4).

Przekonanie, że obywatele to wyżsi urzędnicy, bogacze, szlachta nie przystaje do oświeceniowej wykładni tego terminu. W pismach myślicieli Oświecenia słowo „obywatel" ma podkreślać egalitaryzm ludzi równouprawnionych do uczestnictwa w życiu 
publicznym, mających przywilej wpływu na reprezentacyjny proces stanowienia prawa i konstytuowania władzy kolektywnej. W dyskursach nowotarskich wsi takie ujęcia się nie pojawiają, natomiast słychać wyraźnie nawiązania do hierarchicznych koncepcji porządku społecznego. Słowo „obywatel” gubi w nich egalitarny wydźwięk, nabiera zabarwienia wręcz przeciwnego, służąc do opisu zwierzchności. W efekcie, o ile kategoria "naród” służy do opisu samoidentyfikacji, grupy przynależności określanej słowem "my", o tyle pojęcie "obywatel" wprowadza potencjał obcości, dystansu i nieufności.

Istotnym czynnikiem ułatwiającym przyswojenie kategorii „naród” (w odróżnieniu od słowa "obywatel") był fatalistyczny wymiar przynależności narodowej. W lokalnych wyobrażeniach jak jednostka nie wybiera sobie rodziny, tak też nie wybiera sobie narodu. Pojęcie „obywatel" zawiera potencjalną możliwość wyboru, która powoduje, że kategoria ta nie pasuje do determinującego charakteru porównań gospodarsko-rodowych. W nowotarskich rozmowach słowo "obywatelstwo" było częściej używane niż termin „obywatel". Lokalnie funkcjonowało w kontekście wyrabiania obywatelstwa amerykańskiego. Obywatelstwo jest więc czymś, co można zmienić, przybrać koniunkturalnie, wybrać ze względu na wiążące się z nim korzyści. Z narodowością wiąże się nieuchronność. Podobnie jak można urodzić się w rodzinie dobrej lub złej, tak można należeć do lepszego lub gorszego narodu.

Zestawiając emocjonalnie zaangażowane w rozważania o narodzie i poczucie dystansu, jakie wzbudza termin "obywatel”, można stwierdzić, że idee narodowe i związany z nimi aparat pojęciowy zostały znacznie lepiej ugruntowane w lokalnych dyskursach. Egalitarna koncepcja obywatelstwa, powiązanego z demokracją reprezentacyjną nie pasowała do gospodarskiej metafory źródłowej. Pojęcie „obywatel" nie rezonowało z imaginarium, w którym władza powinna być jak gospodarz, pastoralna, patriarchalna, autokratyczna. Nowotarscy rozmówcy byli zdecydowanymi przeciwnikami władzy kolektywnej. Wymownie o tym świadczyła niechęć, z jaką wypowiadali się o parlamentarzystach, posunięta do pomysłów eksterminacji postów wyszukanymi metodami: tych postów trzeba by wszystkich zagazować! (373:4); Hitlera sprowadzić na nich! (389:1); Samolot pasażerski na ten sejm puścić! (379:4); Powiesić ich wszystkich za jaja! (391:2); Jak Hitler palić w piecu! (373:4). Na opisanie władzy kolektywnej używano określenia rządy parobków, po to by podkreślić, że jest to bardzo niedoskonały rodzaj rządów, na które skazane jest

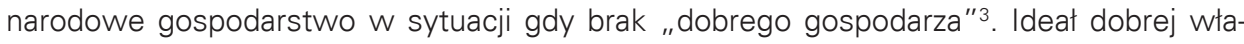
dzy nowotarscy rozmówcy kreślili najczęściej wymieniając pozytywne przykłady. Listę tę rozpoczynał ideał duchowej władzy służebnej, czyli Jan Paweł II. Wśród dobrych włodarzy państwowego gospodarstwa na pierwszym miejscu wymieniano Franca Jozefa ${ }^{4}$, dalej Józefa Piłsudskiego i Edwarda Gierka. Na liście pozytywnych wzorów pojawił się nawet Adolf Hitler i Augusto Pinochet, którzy mieli podkreślać, że: władza dobro, no to jest władza silno! (116:2); To musi być stanowczy człowiek, żeby mógł coś zrobić! Tak jak gazda jest stanowczy! (270:1); To tak jak pasterz idzie owce paść, to som takie, co sie dobrze pasom i takie, co uciekajom. Dla tych to pasterz musi być ostry, musi je kochać i gonić. Kara musi być! Dyscyplina! Żeby sie bali pasterza! $(288: 4,5)$; Żeby stuchać tego pasterza, żeby go kochać. Jak rozkaże żeby iść, jak zawoła, żeby przyjść (327:1). Zarówno przywołane przykłady dobrych władców, jak i cytowane wypowiedzi pokazują, że ideały demokracji reprezentacyjnej nie były ideałami podzielanymi przez rozmówców. Narzekania, irytacje,

\section{-....}

O popularności na wsi polskiej i białoruskiej figury "dobrego gospodarza" pisali Tomasz Rakowski (2009) i Anna Engelking (2012).

4 O galicyjskim micie Franciszka Józefa pisał Zygmunt Fras (1994). 
przekleństwa towarzyszące rozmowom o rządach w Polsce były efektem fundamentalnej odmienności wyobrażeń o ideale władzy funkcjonującym w dyskursach lokalnych i tych wdrażanych przez system polityczno-prawny po 1989 roku.

Przysłuchując się poetyce lokalnych dyskursów, można stwierdzić, że aparat pojęciowy wypracowany przez filozofów oświecenia nie zadomowił się w nowotarskich rozmowach o polityce. Jadwiga Staniszkis przesuwa jeszcze dalej cezurę nieprzyswojonych koncepcji filozoficznych, pisząc, że w zakresie ontologii władzy „katolickie kraje Europy Środkowej (w tym Polska) nie przeszły przez nominalistyczną rewolucję myślową, pozostając w kręgu tomistycznego nominalizmu" (Staniszkis, 2006, s. 61). Uważam, że specyficznym filtrem powodującym zakorzenianie się pewnych idei oraz ignorowanie innych są lokalnie wypracowane kategorie uprzednie, do których pewne koncepcje pasują, a inne nie. Wiejskie kategorie pojęciowe zorganizowane wokół metafory gospodarskiej stanowią rodzaj membrany selekcjonującej wiadomości ze świata przekazywane przez media i wymieniane w codziennych rozmowach. W czasach globalnych przepływów spowodowanych umasowieniem migracji zarobkowych i powszechną dostępnością internetu kategorie narodowe okazują się wciąż bardzo użytecznym narzędziem definiowania i klasyfikowania tożsamości zarówno własnej jak i obcych. Stereotypy narodowe dają wrażenie myślowego opanowania skomplikowanej i zmiennej współczesnej rzeczywistości, dostarczając iluzji przewidywalności świata. „Oszałamiająca różnorodność globalnych zdarzeniowych kaskad" (Appadurai, 2005, s. 230) daje się uchwycić jedynie wtedy, gdy zostanie ujęta w karby kategorii poznawczych zakorzenionych w minionych doświadczeniach oraz interpretacjach nadających im sens. Jeśli można wyobrazić sobie, że świat tak jak rodzinną wieś zamieszkują rody - narody poczucie bezradności odczuwane w obliczu wiadomości ze świata znacznie słabnie. Wyobrażenia skonstruowane na bazie porównania państwa do gospodarstwa sprawdzają się na co dzień jako poznawczy oręż w walce z płynną nowoczesnością. Jakkolwiek „państwo narodowe (...) przechodzi kryzys” (Appadurai, 2005, s. 249) idee narodowe i związana z nimi specyficzna językowa poetyka wciąż trwają, a nawet umacniają się w obliczu "coraz bardziej burzliwych relacji z postnarodowymi Innymi" (Appadurai, 2005, s. 249).

\section{BIBLIOGRAFIA}

Anderson, B. (1997). Wspólnoty wyobrażone (S. Amsterdamski, Tłum.). Kraków: Znak

Appadurai, A. (2005). Nowoczesność bez granic: Kulturowe wymiary globalizacji (Z. Pucek, Tłum.). Kraków: Universitas.

Bourdieu, P. (2006). Dystynkcja: Społeczna krytyka władzy sądzenia (P. Biłos, Tłum.). Warszawa: Scholar.

Bystroń, J. S. (1995). Megalomania narodowa. Warszawa: Książka i Wiedza.

Czaja, D. (2005). Anatomia duszy: Figury wyobraźni i gry językowe. Kraków: WUJ.

Czyżewski, M., Kowalski, S., \& Piotrowski, A. (1997). Rytualny chaos: Studium dyskursu publicznego. Kraków: Aureus.

Dobrowolski, K. (1966). Studia nad życiem społecznym i kulturą. Wrocław: Zakład Narodowy im. Ossolińskich.

Durkheim, E. (1990). Elementarne formy życia religijnego (A. Zadrożyńska, Tłum.). Warszawa: PWN. 
Engelking, A. (2012). Kotchoźnicy antropologiczne studium tożsamości wsi białoruskiej przełomu XIX i XX wieku. Toruń: Wydawnictwo Naukowe UMK.

Foucault, M. (2000). Filozofia, historia, polityka: Wybór pism (D. Leszczyński \& L. Rasiński, Tłum.). Warszawa: PWN.

Fras, Z. (1994). Mit dobrego cesarza. W W. Wrzesiński (Red.), Polskie mity polityczne XIX i XX wieku (ss. 139-152). Wrocław: Wydawnictwo Uniwersytetu Wrocławskiego.

Gellner, E. (1991). Narody i nacjonalizm (T. Hołówka, Tłum.). Warszawa: PIW.

Hobsbawm, E. (2010). Narody i nacjonalizm po 1780 roku: Program, mit, rzeczywistość (J. Maciejczyk \& M. Starnawski, Tłum.). Warszawa: Difin.

Kasznica, S. (1966). Władza. Warszawa: IHN PAN.

Kieniewicz, S. (1982). Historia Polski 1795-1918. Warszawa: PWN.

Kizwalter, T. (1999). O nowoczesności narodu: Przypadek polski. Warszawa: Semper.

Kołakowski, L. (2003). Obecność mitu. Warszawa: Prószyński i Spółka.

Kroh, A. (1999). Sklep potrzeb kulturalnych. Prószyński i Spółka.

Latour, B. (2011). Nigdy nie byliśmy nowocześni: Studium z antropologii symetrycznej (M. Gdula, Tłum.). Warszawa: Oficyna Wydawnicza.

Levy-Bruhl, L. (1992). Czynności umysłowe w społeczeństwach pierwotnych (E. Tarkowska, Tłum.). Warszawa: PWN.

Łuczewski, M. (2012). Odwieczny naród: Polak i katolik w Żmiącej. Toruń: Wydawnictwo Naukowe Uniwersytetu Mikołaja Kopernika.

Malewska-Szałygin, A. (2008). Wyobrażenia o państwie i władzy we wsiach nowotarskich 1999-2005. Warszawa: DiG.

Molenda, J. (1999). Chłopi, naród, niepodległość: Kształtowanie sie postaw narodowych i obywatelskich chtopów w Galicji i Królestwie Polskim w przededniu odrodzenia Polski. Warszawa: Neriton IH PAN.

Ossowski, S. (1984). O ojczyźnie i narodzie. Warszawa: PWN.

Pomian, K. (2004). Europa i jej narody. Gdańsk: Słowo, obraz, terytoria.

Rakowski, T. (2009). Łowcy, zbieracze, praktycy niemocy etnografia człowieka zdegradowanego. Gdańsk: słowo/obraz terytoria.

Rozmowy z góralami o polityce. (2005) (A. Malewska-Szałygin, Red.). Warszawa: Wydawnictwo Trio.

Shils, E. (1957). Primordial, personal, sacred and civil ties. British Journal of Sociology, 8(2), 130-145. https://doi.org/10.2307/587365

Staniszkis, J. (2006). O władzy i bezsilności. Kraków: Wydawnictwo Literackie.

Taylor, C. (2010). Nowoczesne imaginaria spoteczne (A. Puchejda \& K. Szymaniak, Tłum.). Kraków: Znak.

Thomas, W. I., \& Znaniecki, F. (1976). Chłop polski w Ameryce i Europie (M. Metelska, Tłum.). Warszawa: Ludowa Spółdzielnia Wydawnicza.

Tischner, J. (2005) Etyka solidarności oraz Homo Sovieticus. Kraków: Znak.

Turner, V. (2005). Gry społeczne, pola, metafory: Symboliczne działanie w społeczeństwie (W. Usakiewicz, Tłum.). Kraków: WUJ.

Weber, M. (1975). Trzy czyste typy prawomocnego panowania. W W. Derczyński, A. Jasińska-Kania, \& J. Szacki (Red.), Elementy teorii socjologicznych (ss. 339-550). Warszawa: PWN.

Weber, M. (2004). Racjonalność, władza, odczarowanie. Poznań: Wydawnictwo Poznańskie. 